ン酸を減少させなかった。

3) 本効果により, LVAD 駆動が虚血心筋を保護し, 梗塞領域を縮小する可能性が示唆された.
文 献 1) Takano, H. et al.: Trans. Am. Soc. Artif. Intern. Organs 31: 196, 1985.2 2) Pennock, J. L. et al. : Circulation $\mathbf{5 9}(2): 275,1979$. 3) Noda, H. et al.: Life Support Sys. 4 (Suppl. 2) : 35, 1986.

\title{
77 左心補助人工心臓駆動による右心機能への影響
}

一一基礎的および臨床的検討——

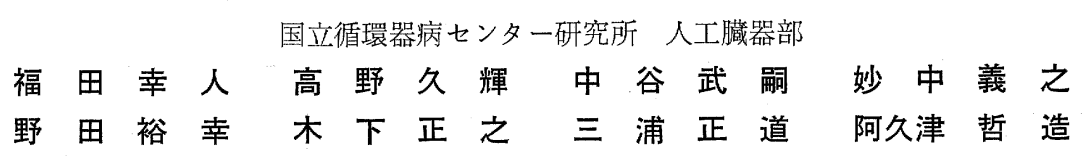

左心補助人工心臟 (LVAD) は，左室の容量負荷を之 り収縮力を軽滅させる，そのため左室と筋束を共有する 右室收縮力が低下し, 右心不全を惹起するという報告が ある1).われわれは, LVAD が右室機能にどのような影 響をおよぼしているかを知るためにヤギを用いた急性お よび慢性実験にて検討している゙2.

\section{目 的}

ヤギを用いた急性実験で, 正常心肺機能に及ぼす LVAD の影響を検討し, 次いで当センターにおいて経 験した LVAD 使用症例の血行動態を基に心臟手術後の 両心不全状態における LVAD の影響，および術前の心 臟疾患の違いによる影響の差異について検討した。

\section{方法}

\section{1. 動物実験}

空気圧駆動ダイアフラム型補助人工心臟を体重約 30 $\mathrm{kg}$ のヤギの左房下行大動脈間比装着し，心拍同期 1 対 1， 1 対 2, また心拍非同期にて駆動した. 右房圧 (RAP), 右室圧 (RVP), 肺動脈圧 (PAP), 左房圧 $(\mathrm{LAP})$, 左室圧 $(\mathrm{LVP})$, 大動脈圧 $(\mathrm{AoP})$ の各内圧, および血液ポンプの拍出量 $(\mathrm{BF})$, 肺動脈流量 $(\mathrm{PAF})$ を測定し，BF/PAF をバイパス率とした．右房にフレキ シブルリザーバを挿入し，右室前負荷を一定とし，バィ パス率を変化させその時の血行動態を測定した．

\section{2. 臨床例}

1982 年から 1986 年の間に経験した 13 例のうち, 経過 中に LVAD の ON/OFF を施行できた 5 例であり，そ の内訳は, 心室中隔欠損に肺高血圧合併例の根治術後 1 例 (case 1), 急性心筋梗塞 (AMI) 飞中隔穿孔 (VSP)
を合併し穿孔部閉鎖術後 2 例（case 2，3），AMI 亿よる 心原性ショック 2 例（case 4，5）である. 全症例とあ, 良好な全身循環が維持され，LVAD からの離脱に成功 した.

\section{結果}

動物実験においては，PAF は mRAP の上昇ととも に增加するが mRAP が $15 \mathrm{mmHg}$ 以上では逆に減少し た、また LVAD の駆動により増加し，バイパス率の大 きいむのほどより增加量が大きかった，mPAPは, mRAP の上昇とと屯に増加し, LVAD の駆動により非 駆動時より低下し, バイパス率の高いものほど mPAP の低下量が大きかった（図 1 ). 全肺血管抵抗は mRAP の増加につれ増加する傾向を認め, LVAD 駆動によ り低下する傾向を認めた。 一方, 右室一回仕事量は, mRAP の増加により増加するが, LVAD の駆動, 非 駆動にかかわらずほぼ同一の值をとり変化を認めなかっ た. 以上より, LVAD は正常心肺であれば LAP を減 少させることで mPAP が減少し右室の後負荷を低下さ せ, また一方, 心拍出量を增加させるが, 右室の仕事量 を増加させないととが認められた。すすなわち, 左室補助 のみならず, 右室後負荷軽減効果により右室補助を行っ ていると考えている. 臨床例においては, 発症前に肺高 血圧のなかった AMI 症例の case 2,3，4，5 は LVAD 駆動により mPAP がそれぞれ平均 2.3，2.8，2.5，6.0 $\mathrm{mmHg}$ 之非駆動時に比べ有意に低下した。 また PAF を測定しえた case 2, 3 では, LVAD 駆動によりそれ ぞれ平均 $0.51,0.50 \mathrm{l} / \mathrm{min}$ 増加した（図 2). 装着前に 肺高血圧を合併していた case 1 では, VSD 閉鎖術によ り mPAP は低下したが, LVAD 駆動により mPAP は 

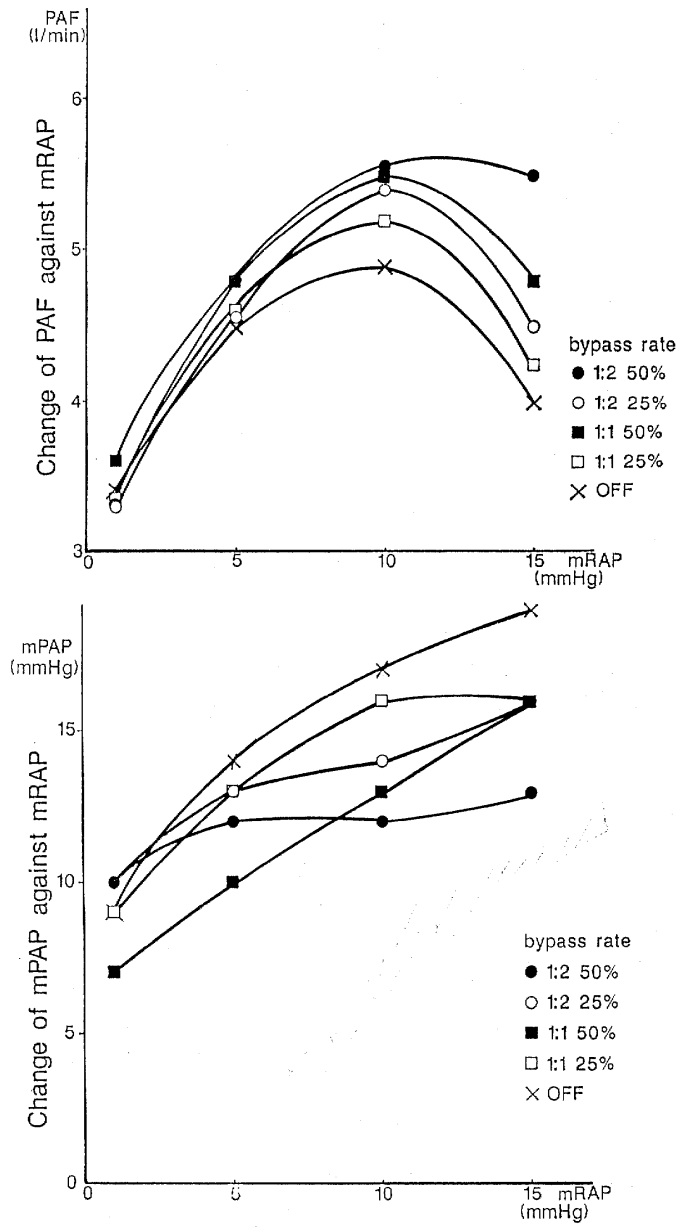

図 1

非駆動時にくらべて $1.8 \mathrm{mmHg}$ 減少傾向を認めた（困 3).

\section{考 察}

心原性ショックにより LVAD を装着した case 5 以 外は，いずれも体外循環から離脱困難なために適応とな ったものであり，装着時は程度の差こそあれ両心不全状 態であると考えられる. また LVAD の on，off を施行 しえたのはある程度まで心機能が回復してきてからであ るため, 術直後の LVAD の影響は直接にはわからない が，著明な右心不全以外であれば LVAD は両心不全時 でも有效と考えられる．動物実験で明らかになったよう にLVAD の右室に対する補助効果は，直接的に冠血流 量を増加させて右心室の収縮力を改善する以外に, 間接 的に LAP を下げることによる PAP の低下によりもた

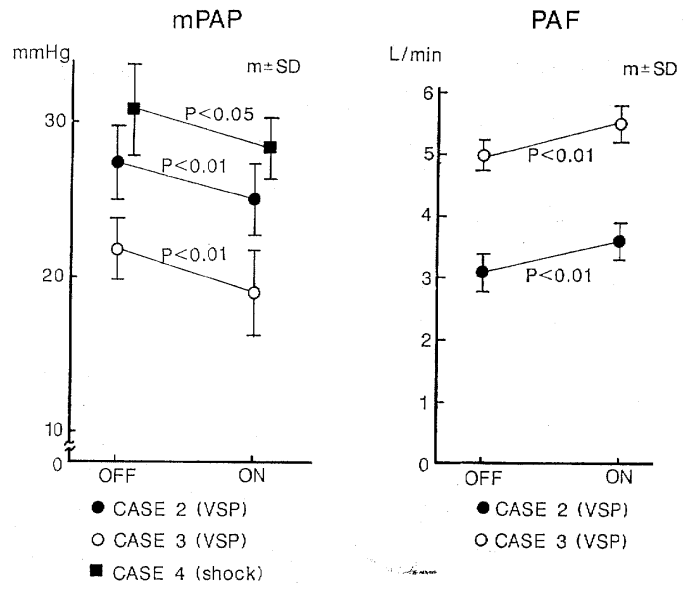

図 2

$$
\begin{aligned}
& \text { CASE } 1 \\
& \text { VSD } 2 \text { Y M } \\
& \begin{array}{ll}
\text { RA } & (0) \\
\text { RV } & 88 /-3(1) \\
\text { PA } & 88 / 51(67) \\
\text { PC } & (7) \\
\text { LV } & 93 / 2(6) \\
\text { AO } & 93 / 57(74)
\end{array} \\
& Q p / Q s=3.06
\end{aligned}
$$

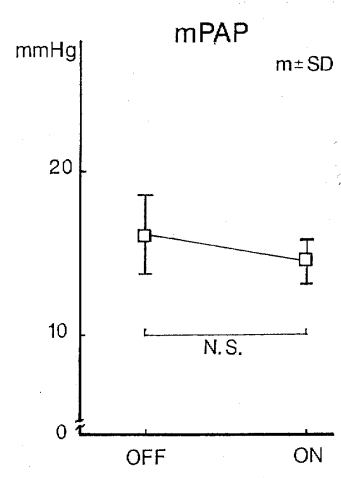

図 3

らされてくる右室後負荷軽減効果である．とのため，肺 血管抵抗が高い場合には LVAD による間接的な右室補 助効果は期待できないと考えられるが, case 1 のように 術前肺高血圧を伴う場合でも肺血管抵抗がそれほど高く ないため LVAD による右室補助効果が期待できたと考 える。

\section{結語}

1）動物実験により，LVAD は LAP を低下させ右 室後負荷を軽減し，心拍出量を増加させる効果があるこ とが認められた。

2) 臨床例において，回復期では動物実験と同様の結 果を認めた. したがって，軽度の右心不全を伴う術後の 両心不全状態において右室後負荷軽減効果が認められ ると考える。

3）術前は肺高血圧を合併した症例でも，術後肺高血 圧が軽減すれば同様の右室後負荷軽減効果が期待しうる 


\section{8 補助人工心臓駆動中の患者管理の問題点}

\section{東北大学 胸部外科, 抗研電子医学*

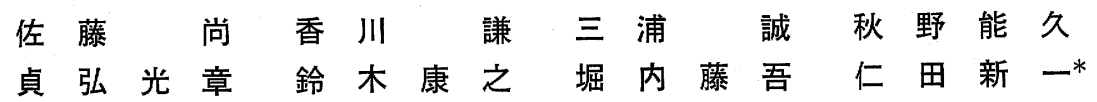

開心術後の重篤な LOS 亿対する補助人工心臟（以下 $\mathrm{VAD})$ の使用は本邦でむ 50 例を越え，その強力な心補 助効果は広く認められるところとなっている。しかし心 機能が回復し，VAD を離脱できたものの，術後合併症 により失う結果となった症例も少なくない，合併症の原 因は, 術前加ら存在した臓器不全因子, 適応決定の時期 に関連した問題等, VAD 駆動開始前に求められるもの のみならずVAD 駆動中の管理方法に起因するものあ あると思われるので, 今回, その患者管理の問題点につ き検討を加えた。

\section{対 象}

現在まで東北大学胸部外科にてVAD の臨床使用が 施行されたのは計 7 例であるが, VAD が有効で血行動 態の改善のみられた 5 例を検討の対象とした．内訳は急 性心筋梗塞 2 例, 弁膜症 3 例で，いずれも開心術後重篤 な心不全に宿った症例であった．1例は心機能の改善は 認められたものの末梢循環不全による hyperdynamic failure の状態で結局 VAD を離脱しえないまま死亡し た. 他の 4 例中， 3 例は VAD 離脱後何らかの合併症 により術後 18〜123 日に死亡，長期遠隔生存の得られた のは1例であった.

\section{結果}

表 1 亿検討対象となった症例に合併した臟器不全の内 容を示す，症例 1 は 58 歳女性, Ebstein 奇型に対する 三尖弁置換術後右心不全で RVAD を 7 日間駆動し，術 後 18 日目に腎不全, 敗血症にて死亡した。 感染症の原 因はVAD のカニューレ走行にあると考えられ，以後 装着方法の改善により解決をみている。腎不全は VAD 駆動中止後 CVP の上昇とともに出現したが，原因は VAD 駆動開始の遅れに求められ, 駆動中の管理方法と
表 1 補助心臟使用に合併した蔵器不全

\begin{tabular}{|c|c|c|c|c|c|c|c|}
\hline \multirow{2}{*}{ 症例 } & \multirow{2}{*}{ 嗙断（術式） } & \multirow{2}{*}{$\begin{array}{l}\text { VAD } \\
\text { 使用期 } \\
\text { 間 }\end{array}$} & \multicolumn{4}{|c|}{ 合併臟器不全 } & \multirow{2}{*}{ 転帰（死因） } \\
\hline & & & 腎 & 肺 & 肝 & 脳 & \\
\hline 1 & Ebste & ） 7日 & H & H & - & - & (18 pod, sepsis) \\
\hline 2 & ReN & 70日 & 计 & H & + & - & $\begin{array}{l}\text { 死 } \begin{array}{c}\text { (70 pod, } \\
\text { sepsis) }\end{array} \\
\text { CHF, }\end{array}$ \\
\hline 3 & A-C バイパス & 7日 & + & - & - & - & 生 存 \\
\hline 5 & MVK & 4日 & + & H & - & H & $\begin{array}{l}\text { (97 死 } \text { pod, }_{\text {sepsis }}\end{array}$ \\
\hline 6 & AMI, VSP & 20日 & + & $\#$ & - & - & $\begin{array}{l}\text { 死 亡 } \\
\text { (123 pod, sepsis) }\end{array}$ \\
\hline
\end{tabular}

+ Fatal, + Moderate severe, - none 症例番号は当施設での通し番号で記載した.

は無関係と思われた，症例 2 は前述の LVAD を離脱し えなかった症例で腎不全，呼吸不全を合併し，敗血症に て死亡した。 症例 3 は長期生存例であるが術後 4 日目に 人工呼吸から離脱, 拔管が可能であった. BUN が術後 2 週の時点で 80 台之上昇したが尿量に異常は認められ なかったので放置, BUN は一過性に正常化した. 症例 5,56 歳男性, MVR および TAP 術後で LVAD 4 日間駆動, 離脱した，術後 3 日目に置換弁由来の脳塞栓 症を合併し，人工呼吸の継続を余儀なくされたまま術後 97 日目に MOF，敗血症にて死亡した．とくに MVR 術後 LVAD 駆動に当たっては早期から抗凝固療法を開 始すべきと反省させられた. 症例 6,65 歳女性, AMI, VSP 汇対するVSP 閉鎖術後 20 日間 LVAD 駆動し, 離脱に成功した。術後呼吸機能の回復は早かったが, 早 期抜管を躊躇するうちに閉塞性呼吸障害を合併して拔管 の時期を失した. 本症例です BUN の上昇が認められ たが尿量は保たれておりときに粲不全としての治療は行 わなかった. 術後 123 日目, 人工呼吸から離脱不能のま ま全身性の感染症にて死亡した。

表 1 亿見られるように死亡症例は人工呼吸から離脱で 